Ігор ОПАЦЬКИЙ,

orcid.org/0000-0002-6786-3295 кандидат історичних наук, викладач кафедри історії України Уманського державного педагогічного університету імені Павла Тичини

(Украӥна, Умань)

igor.opatskiy@gmail.com

\title{
ЕТНОГРАФІЧНІ ДОСЛІДЖЕННЯ МИКОЛИ БІЛЯШІВСЬКОГО НА ЧЕРКАЩИНІ
}

У статті на основі аналізу біографічних даних та наукової спадщини Миколи Федотовича Біляшівського проаналізовано внесок вченого у становлення музейної справи в Украӥні. Простежено формування інтересу М. Біляшівського до украӥнської минувшини та вивчення ним життя $і$ побуту украйнців у різні історичні епохи. Зазначено, щзо перші наукові кроки М. Білямівський здійснив під впливом професора B. Антоновича. Узагальнено етнографічні дослідження вченого на Черкащині, зокрема збір усноісторичного матеріалу серед жителів с. Пекарів про Тараса Шевченка. Курінний.

Ключові слова: Микола Біляшівський, Черкащчна, етнографічні студї, Тарас Шевченко, Петро

Ihor OPATSKYI,

Candidate of Historical Sciences, lecturer of history of Ukraine Department

Pavlo Tychyna Uman State

Pedagogical University (Uman, Ukraine)

igor.opatskiy@gmail.com

\section{ETHNOGRAPHIC RESEARCH OF MYKOLA BILYASHIVSKY IN CHERKASY REGION}

The article, based on the analysis of biographical data and scientific heritage of Mykola Fedotovych Bilyashivsky, analyzes the scientist's contribution to the formation of the museum business in Ukraine. The formation of M. Bilyashivsky's interest in the Ukrainian past and his study of the life and way of life of Ukrainians in different historical epochs is traced. It is noted that the first scientific steps were taken by M. Bilyashivsky under the influence of Professor V. Antonovych. The ethnographic researches of the scientist in Cherkasy region are generalized, in particular the collection of oral historical material among the inhabitants of the village of Pekari about Taras Shevchenko.

Academician Mykola Bilyashivsky made a significant contribution to the development of Ukrainian archeology, ethnography and museum work. Starting with the work on the Horodok Museum of Fyodor Steingel, M. Bilyashivsky carried out ethnographic expeditions, collected and recorded a variety of oral history and folklore material. On the territory of Cherkasy region M. Bilyashivsky recorded the memories and testimonies of the villagers Pekari about Taras Shevchenko. However, M. Bilyashivsky served Ukrainian ethnography the most, heading the Kyiv Museum. Among other things, an ethnographic department was created in the museum, which at the beginning of 1916 numbered 27,700 items. To replenish the funds, the ethnographic department carried out systematic expeditions, during which they collected and bought various items, received a collection of towels, embroidery, carpets, etc. from Ukrainian collectors.

Bilyashivsky had friendly relations with the members of Uman branch of the Kyiv Society for the Protection of Antiquities and Art (in particular with P. Kurinny and Kh. Yashchurzhynsky). Among the tasks of the society was the collection and search of historical information about the Uman region, conducting archaeological and folklore and ethnographic research of the region, preservation of ancient monuments. He provided all possible assistance, at least with advice, in the organization of monument protection and museum work in Uman.

After the forced removal from museum affairs, M. Bilyashivsky was able to devote more time and effort to archaeological research. In 1925, together with P. Kurinny, he went to continue the archaeological research of the 
Trypillia settlement in the village of 1904. Borysivka, Illinetsky district, Vinnytsia region. During the expedition, artifacts were found that allowed researchers to identify the settlement as a special type of Trypillia culture.

Key words: Mykola Bilyashivsky, Cherkasy region, ethnographic studies, Taras Shevchenko, Petro Kyrinnyi.

Постановка проблеми. Наприкінці XIX - на початку XX ст. зусиллями подвижників української національної справи зростав інтерес до української минувшини, здійснювалися систематичні наукові дослідження, що мали на меті всебічне дослідження української культури та історії. Чільне місце серед українознавчих досліджень займали етнографічні експедиції різними населеними пунктами, під час яких дослідники вивчали минувшину, записували фольклорний матеріал, знаходили цінні пам'ятки народного мистецтва. Значну кількість досліджень було здійснено на території Південної Київщини, зокрема Черкащини. Етнографічні та фольклористичні дослідження Черкаського регіону др. пол XIX - початку XX ст. здійснювала низка відомих вчених та громадських діячів (П. Куліш, П. Чубинський, М. Драгоманов, П. Демуцький та ін.). Однак до сьогодні малодослідженою залишається етнографічна діяльність на Черкащині академіка Миколи Федотовича Біляшівського (1867-1926).

Аналіз досліджень. Завдячуючи українським дослідникам сьогодні в численних довідникових та енциклопедичних статтях, дослідженнях 3 історії музейної справи в Україні та наукових розвідках належно висвітлено життєвий та науковий шлях М. Біляшівського. Одні з перших біографічних розвідок про М. Біляшівського було опубліковано у 1926 р. в 9-ій книзі «Записок Історикофілологічного відділу ВУАН». Біографічні відомості та розвідки про внесок М. Біляшівського в українську археологію, нумізматику, мистецтво, музейну та громадську роботу опублікували Д. Багалій, А. Винницький, П. Курінний, В. Ляскоронський, Д. Щербаківський, С. Єфремов (Записки історичнофілологічного відділу ВУАН, 1926). В радянський період у наукових публікаціях не аналізувалася суспільно-політична діяльність М. Біляшівського, акцент робився на його науково-культурну роботу (Бахмат, 1967). Однак українські вчені в діаспорі наголошували на важливій ролі М. Біляшівського під час національного культурного ренесансу. Так, П. Курінний 1954 р. у 
рубриці «Провідні ідеї і люди української науки», що виходила в газеті «Шлях перемоги» опублікував біографічний нарис про М.Біляшівського, в якому наголошував на подвижницькій праці вченого та називав його «натхенним працівником ренесансу української культури в ХХ ст.» (Курінний, 1954).

Грунтовне дослідження біографії та ролі М. Ф. Біляшівського у науковому, культурному та громадському житті України здійснено Л. Дідух (Дідух, 2005). Я. Затилюк та Ю. Осташевська здійснили археографічну публікацію тексту автобіографії М. Біляшівського та доповнили ii розлогим дослідницьким i джерелознавчим коментарем (Затилюк, Осташевська, 2019). А. Примак закцентувала увагу на етнографічних студіях М. Біляшівського (Примак, 2008).

Мета статті. Продовжуючи наукові пошуки істориків маємо на меті проаналізувати етнографічні дослідженні Миколи Біляшівського на Черкащині та його участь у пам'яткоохоронній справі на Уманщині.

Виклад основного матеріалу. Микола Біляшівський народився 12 жовтня 1867 р. в Умані у священницькій родині. Дід був дияконом в одному із сіл Уманщини, батько був вчителем церковно-парафіяльної школи. Однак дитинство М. Біляшівського пройшло не в Умані, а в с. Острійки, неподалік Білої Церкви, куди переїхала родина Біляшівських після прийняття батьком священницького сану. Ще малою дитиною Микола захопився збиранням різноманітних камінців, кремінців та археологічних знахідок. У четвертому класі київської гімназії захопився збиранням та колекціонуванням монет, частину з яких купував за «сніданкові гроші». Коли Миколі було 6-7 років, за його спогадами, їх сім'я переїхала до Києва, де батько зайняв місце священника при Київській тюрмі (Затилюк, Осташевська, 2019: 398).

У 1881 р. Микола Біляшівський познайомився з очільником Церковноархеологічного музею Миколою Петровим (1840-1921) та долучився до музейної справи. М. Петров давав цікаві пояснення відвідувачам, входив у розмови, що стосувалися старовини i таким чином заохочував людей поповнювати музейні фонди. У 1883-1886 рр. М. Біляшівський «познайомився 3 цілим гуртком нумізматів, який існував тоді в Києві». Приблизно в цей же час 
захопився і археологією, здійснив спроби перших досліджень (Затилюк, Осташевська, 2019: 401).

У 1885 р., після закінчення гімназії, вступив на юридичний факультет Київського університету Св. Володимира. Хоча інтереси юнака були ближчими до історико-філологічного факультету, однак на юридичному факультеті було менше «класичних» дисциплін, тому студент вирішив навчатися на юридичному факультеті, але відвідувати цікаві лекції історико-філософського факультету. Систематично слухав лекції В. Антоновича «Русские древности», які склали на студента глибоке враження та сприяли ще дужчому захопленню археологією. У 1887 р. В. Антонович запросив М. Біляшівського долучитися до археологічних розкопок на Сквирщині, а вже у 1888 р. редакція «Київської Старовини» запросила молодого дослідника до роботи у редакції. 3 того часу в М. Біляшівського відбулася чітка самоідентифікація «свого я» та сформувалося гасло - працювати тільки для України (Курінний, 1954).

Восени 1892 р. М. Біляшівський переїхав до Москви, де був слухачем природничого факультету Московського університету та працював у Архіві міністерства юстиції. Проживаючи в Москві долучився до участі в археологічному товаристві і товаристві «Природознавства, антропології та етнографії». На річних зборах товариства виступав з доповіддю про знахідки кам'яної доби, які було знайдено під час досліджень Княжої Гори. Взимку 1893 р. познайомився з фольклористом та етнографом, дослідником чумацьких пісень, старшим братом Панаса Мирного Іваном Рудченком (1845-1905). Він запропонував М. Біляшівському очолити посаду завідуючого архівом колишнього фінансового управління Царства Польського при Варшавській казенній палаті.

У 1893 р. М. Біляшівський здійснив записи народних розповідей про Тараса Шевченка в селі Пекарі неподалік від Канева. Це село не випадково було обраним для здійснення етнографічних досліджень народної пам'яті про Т. Шевченка, адже в цьому селі поет побував незадовго до смерті. Багато селян особисто бачили Т. Шевченка, спілкувалися 3 ним, тому те, наскільки 
збереглися реальні біографічні відомості про Кобзаря та наскільки вони обросли легендами особливо цікавили М. Біляшівського. Дослідник не встиг записати багато свідчень про поета, хоча, за його спостереження, кожен селянин старшого віку міг що-небудь розповісти про Шевченка.

Т. Шевченко у 1859 р. під час подорожі Україною відвідав рідну Кирилівку, потім відправився до Корсуня після якого вирушив до М. Максимовича на хутір Михайлова гора. 15-20 липня 1859 р., на шляху до Прохорівки, Шевченко на кілька днів зупинився в с. Пекарі. На думку М. Біляшівського метою відвідування Т. Шевченком цього села був пошук гарного місця, на якому можна було б збудувати будинок та доживати віку серед розкішної української природи. 3 метою пошуку місця під будівництво Шевченко і здійснював подорожі селом, про які збереглася пам'ять у селян (Беляшевский, 1894).

У розповідях очевидців важко знайти невідомі факти 3 біографії Т. Шевченка, однак для дослідників вони цікаві в першу чергу тим, які відносини мав поет з простим народом, який він оспівував у своїй творчості. М. Біляшівський звернув увагу, що Шевченко-поет чи Шевченко-художник мало цікавив селян, їм куди цікавіше було розмірковувати про Шевченка як людину. Народ цінував безмірну любов Шевченка до себе, його співчуття та бажання здобути волю для народу.

В народних уявленнях Т. Шевченко був надзвичайною людиною. Адже його селянське походження i те, що йому вдалося в часи кріпацтва досягти таких висот свідчило про надзвичайні можливості поета. Серед народу зустрічалися твердження, що «Шевченко лицар дуже великий був», дехто навіть наділяв його надзвичайними можливостями, як героїв народних переказів: i «великим характерником» його називали, і те, що він «такий буде лицем зараз, через час він і переміниться» тощо. Більшість розповідей про юність Шевченка були побудовані на реальних фактах його біографії, лише в деяких випадках скорочених і поданих у простішій формі. «Він пас гуси, а 
панські діти учились у школі, а Тарас підійшов під вікно, да так і научився» (Беляшевский, 1894: 369).

Не зважаючи на те, що в селі Пекарях Тарас Шевченко перебував кілька днів, однак пам'ять про нього надовго закарбувалася в місцевого населення. Старожили згадували: «він жив недовго, побув днів два чи три, у людей не був, а побув у попа Маковецького. Під Княжою єсть долина Пластунка, тепер там яр, а перш була така гарна долина, там був шинк, держав його дід Прохір, та й баба там його була. Горілка там дуже дешева, осьмина стоїла там два шаги, а в Каневі чотири шаги. На зелені святки сходились туди хлопці й дівчата, та й старі, з Канева, брали в тому шинку горілку, да розходились по долині; ото пили, а потім заходжувались биться. В тім шинку бував і Шевченко» (Беляшевский, 1894: 365).

Люди, яким вдалося особисто побачити Шевченка, переповідали свої враження про цю подію з покоління в покоління. Найбільше селяни згадували про доброту поета, його щедрість та зацікавленість народним фольклором та місцевостями села. Загалом М. Біляшівському вдалося зібрати усноісторичні свідчення, які стали основою для з'ясування народних уявлень про біографію поета, його особисті риси характеру. Дослідник зазначав, що записав тільки незначну частину спогадів мешканців села Пекарів і планував продовжити фольклорно-етнографічні експедиції Черкащиною для запису інформації про Т. Шевченка.

Невдовзі М. Біляшівський переїхав до Варшави. Знаходячись у Варшаві дослідник працював у місцевих бібліотеках та архівах, досліджував матеріали 3 історії України. У цей час тісно товаришував з родиною Федора Штейнгеля та спільно з ним працював над розробкою музею Волинської губернії та був його фактичним директором. За задумом М. Біляшівського музей мав складатися 3 природничого та культурно-історичного відділу. До останнього мали б входити антропологічний, археологічний, історичний, етнографічний відділи, а також архів, тематична бібліотека та фотографії. М. Біляшівський організовував експедиції з дослідження Волині, спільно з членами експедиції подорожував 
селами Волині, де здійснював археологічні розкопки, збирав етнографічний матеріал та фотографував пам'ятки історії і культури (Примак, 2008).

Працюючи у Варшаві М. Біляшівський час від часу приїздив до Києва. У 1894 р. він остаточно переїздить до Києва, де працював на посаді бібліотекаря в Київському політехнічному інституті і присвятив себе ідеї створення українського національного музею в Києві, який би був, за висловом П. Курінного «базою української науки та кузнею національної свідомості» (Курінний, 1954). Ускладнювали роботу над створенням музею московськоцарські заборони та відсутність матеріальних засобів. Незважаючи на різноманітні труднощі, завдячуючи спільним зусиллям української інтелігенції та меценатів (в першу чергу родин Терещенків та Ханенків) Київський художньо-промисловий і науковий музей імператора Миколи Олександровича (в народі ще відомий під назвами Київський музей старожитностей і мистецтв або Київський міський музей) було збудовано і урочисто відкрито 30 грудня 1904 р. До 1923 р. незмінним очільником музею був М. Біляшівський. 3 поміж інших, в музеї було створено етнографічний відділ, який на початок 1916 р. налічував 27700 одиниць зберігання. Для поповнення фондів етнографічний відділ здійснював систематичні експедиції, під час яких збирали та купували різноманітні предмети, приймали у дарунок від українських колекціонерів колекції рушників, вишивок, килимів тощо (Примак, 2008 :190).

Одночасно $з$ творенням музею М. Біляшівський зосередив свою увагу на збиранні матеріалів української етнографії з метою використання їх як суто наукового історичного матеріалу. Організована ним у 1906 р. в Києві велика виставка українського народного мистецтва та кустарної промисловості «Київська кустарна виставка» дала поштовх до створення мистецьких промислових шкіл та майстерень. На цій виставці вперше експонувалося народне мистецтво майже всієї української етнічної території (Курінний, 1954).

У 1913 р., $з$ ініціативи Хрисанфа Ящуржинського та інших активних уманчан, в Умані було засновано Уманське відділення Київського товариства охорони пам'яток старовини і мистецтва. Серед завдань товариства був збір та 
пошук історичної інформації про Уманщину, проведення археологічних та фольклорно-етнографічних досліджень краю, збереження пам'яток старовини. М. Біляшівський мав дружні взаємини з членами цього товариства (зокрема 3 П. П. Курінним та Хр. Ящуржинським) та надав посильну допомогу, бодай порадами, з організації в Умані пам'яткоохоронної і музейної справи (Курінний, 1918).

Зі спогадів П. Курінного відомо, що $з$ початком революції 1917 р. М. Біляшівський переймався долею історичних знахідок і приблизно третину знайдених під час археологічних досліджень артефактів відкладав Для Львова. «... хто його знає, чим усе це скінчиться (революція), де пропадуть наші скарби, а де залишаться. Треба мати десь захоронок нашої культури» (Курінний, 1954). I дійсно, у 1923 р. на посаду директора Київського музею замість М. Біляшівського було призначено комуніста А. Винницького. Під керівництвом останнього почалося «розривання на шматки» дітища М. Біляшівського: картини українських майстрів віддано до російської картинної галереї, археологічний відділ перенесено до Музею суспільних формацій на території Києво-Печерської Лаври. За наказом радянської влади зі збірок народного мистецтва було понищено фото та негативи церков, ікон, речей церковного вжитку. Кращі килими видавалися для оздоблення осель партійного керівництва, а зразки національного одягу видавалися акторам. Кращі антикварні речі були вилучені зі збірок музею для продажу закордон, щоб здобути валюту.

Після вимушеного відсторонення від музейних справ М. Біляшівський більше часу та зусиль зміг присвятити археологічним дослідженням. У 1925 р. він спільно з П. Курінним поїхав продовжити розпочаті у 1904 р. археологічні дослідження трипільського поселення в с. Борисівки Іллінецького району на Вінничині. Під час експедиції було знайдено артефакти, які дали змогу дослідникам ідентифікувати поселення як особливий тип трипільської культури. 
Висновки. Таким чином, академік Микола Біляшівський зробив значний внесок в розвиток української археології, етнографії та музейної справи. Починаючи 3 роботи над Городоцьким музеєм Федора Штейнгеля $\mathrm{M}$. Біляшівський здійснював етнографічні експедиції, збирав та записував різноманітний усноісторичний $\mathrm{i}$ фольклорний матеріал. На території Черкащини М. Біляшівський записував спогади та свідчення селян с. Пекарі про Тараса Шевченка. Однак найбільше М. Біляшівський прислужився український етнографії очолюючи Київський музей. 3 поміж інших, в музеї було створено етнографічний відділ, який на початок 1916 р. налічував 27700 одиниць зберігання. Для поповнення фондів етнографічний відділ здійснював систематичні експедиції, під час яких збирали та купували різноманітні предмети, приймали у дарунок від українських колекціонерів колекції рушників, вишивок, килимів тощо.

\section{СПИСОК ВИКОРИСТАНИХ ДЖЕРЕЛ І ЛІТЕРАТУРИ}

Бахмат, 1967 - Бахмат К. 100 років 3 дня народження відомого археолога та етнографа М.Ф. Біляшівського // Украӥнський історичний журнал. 1967. № 10. С. 112-113.

Беляшевский, 1894 - Беляшевский Н. Рассказы крестьян с. Пекарей о Т. Г. Шевченко // Киевская старина. 1894. Т. 44. № 2. С. $165-181$.

Дідух, 2005 - Дідух Л. Академік М.Ф.Біляшівський у науковому, культурному та громадському житті України (кінець XIX - перша чверть XX ст.): автореф. дис. канд. іст. наук: 07.00.01. К., 2005. 17 с.

Записки історично-філологічного відділу, (1926) - Записки історично-філологічного відділу ВУАН (1926). К., 1926. Кн. 9. С. 1-59.

Затилюк, 2019 - Затилюк Я. «Пам’яті М. Біляшівського» - рукописний спомин з архіву Всеукраїнської академії наук та друковані некрологи 1926 року. Науковий вісник Наиіонального музею історії України, (5), 94-101.

Затилюк, Осташевська, 2019. - Затилюк Я., Осташевська Ю. Академік Микола Федотович Біляшівський та його персональний життєпис: публікація джерела і перспективи дослідження. Науковий вісник Національного музею історії Украӥни, (4), 390-410.

Курінний, 1954 - Курінний П. Академік Микола Федотович Біляшівський // Шлях перемоги. 1954. №13-15.

Курінний, 1918 - Курінний П. 3 культурного життя Уманщини. 3 приводу 5-тої річниці Уманського відділу «Київського Товариства Охорони Пам'яток Старовини» // «Союз». Умань, 1918 р. (зберігся відбиток).

Нестуля, Нестуля, 2020 - Нестуля О.О., Нестуля С.І. Роль М.Ф. Біляшівського у створенні музею Ф.Р. Штенгеля у с. Городок на Волині // Наукові записки Інституту політичних і етнонаціональних досліджень ім. I.Ф. Кураса НАН Украӥни, 2012. С. 257-264

Примак, 2008 - Примак А. Етнографічні студії М. Ф. Біляшівського // Музейний збірник: Зб. наук. пр. К.: ІМФЕ ім. М.Т. Рильського НАН України, 2008. С. 188-194.

\section{REFERENCES}

Bakhmat, 1967 - Bakhmat K. 100 rokiv z dnia narodzhennia vidomoho arkheoloha ta etnohrafa M.F. Biliashivskoho [100 years since the birth of the famous archaeologist and ethnographer MF Bilyashivsky] // Ukrainskyi istorychnyi zhurnal. 1967. № 10. S. 112-113 [in Ukrainian].

Beljashevskij, 1894 - Beljashevskij N. Rasskazy krest'jan s. Pekarej o T. G. Shevchenko [Peasants' Stories from village Pekari about T. G. Shevchenko] // Kievskaja starina. 1894. T. 44. № 2. S. 165-181 [in Russian]. 
Didukh, 2005 - Didukh L. Akademik M.F.Biliashivskyi u naukovomu, kulturnomu ta hromadskomu zhytti Ukrainy (kinets XIX - persha chvert XX st.): avtoref. dys. kand. ist. nauk: 07.00.01. [Academician M. F. Bilyashivsky in the scientific, cultural and public life of Ukraine (end of XIX - first quarter of XX century)]. K., $2005.17 \mathrm{~s}$ [in Ukrainian]. Zapysky istorychno-filolohichnoho viddilu -Zapysky istorychno-filolohichnoho viddilu VUAN. K., 1926. Kn. 9. S. 159 [in Ukrainian].

Zatyliuk, 2019 - Zatyliuk Ya. «Pam’iati M. Biliashivskoho» - rukopysnyi spomyn z arkhivu Vseukrainskoi akademii nauk ta drukovani nekrolohy 1926 roku. [«In Memory of M. Bilyashivsky» is a handwritten memoir from the archives of the All-Ukrainian Academy of Sciences and printed obituaries of 1926.] // Naukovyi visnyk Natsionalnoho muzeiu istorii Ukrainy, (5), 94-101 [in Ukrainian].

Zatyliuk, Ostashevska, Yu. 2019. - Zatyliuk Ya., Ostashevska Yu. Akademik Mykola Fedotovych Biliashivskyi ta yoho personalnyi zhyttiepys: publikatsiia dzherela i perspektyvy doslidzhennia. [Academician Mykola Fedotovych Bilyashivsky and his personal biography: publication of the source and prospects of the research] Naukovyi visnyk Natsionalnoho muzeiu istorii Ukrainy, (4), 390-410 [in Ukrainian].

Kurinnyi, 1954 - Kurinnyi P. Akademik Mykola Fedotovych Biliashivskyi [Academician Mykola Fedotovych Bilyashivsky] // Shliakh peremohy. 1954. №№13-15[in Ukrainian].

Kurinnyi, 1918 - Z kulturnoho zhyttia Umanshchyny [From the cultural life of the Uman] (unpublished) [in Ukrainian]. Nestulia, Nestulia, 2020 - Nestulia O.O., Nestulia S.I. Rol M.F. Biliashivskoho u stvorenni muzeiu F.R. Shtenhelia u s. Horodok na Volyni [The role of M. Bilyashivsky in the creation of the Stengel's museum in the village. A town in Volyn] // Naukovi zapysky Instytutu politychnykh i etnonatsionalnykh doslidzhen im. I.F. Kurasa NAN Ukrainy, 2012. S. 257-264 [in Ukrainian].

Prymak, 2008 - Prymak A. Etnohrafichni studii M. F. Biliashivskoho [Ethnographic studies of Mykola Bilyashivsky] // Muzeinyi zbirnyk: Zb. nauk. pr. K.: IMFE im. M.T. Rylskoho NAN Ukrainy, 2008. S. 188-194 [in Ukrainian]. 